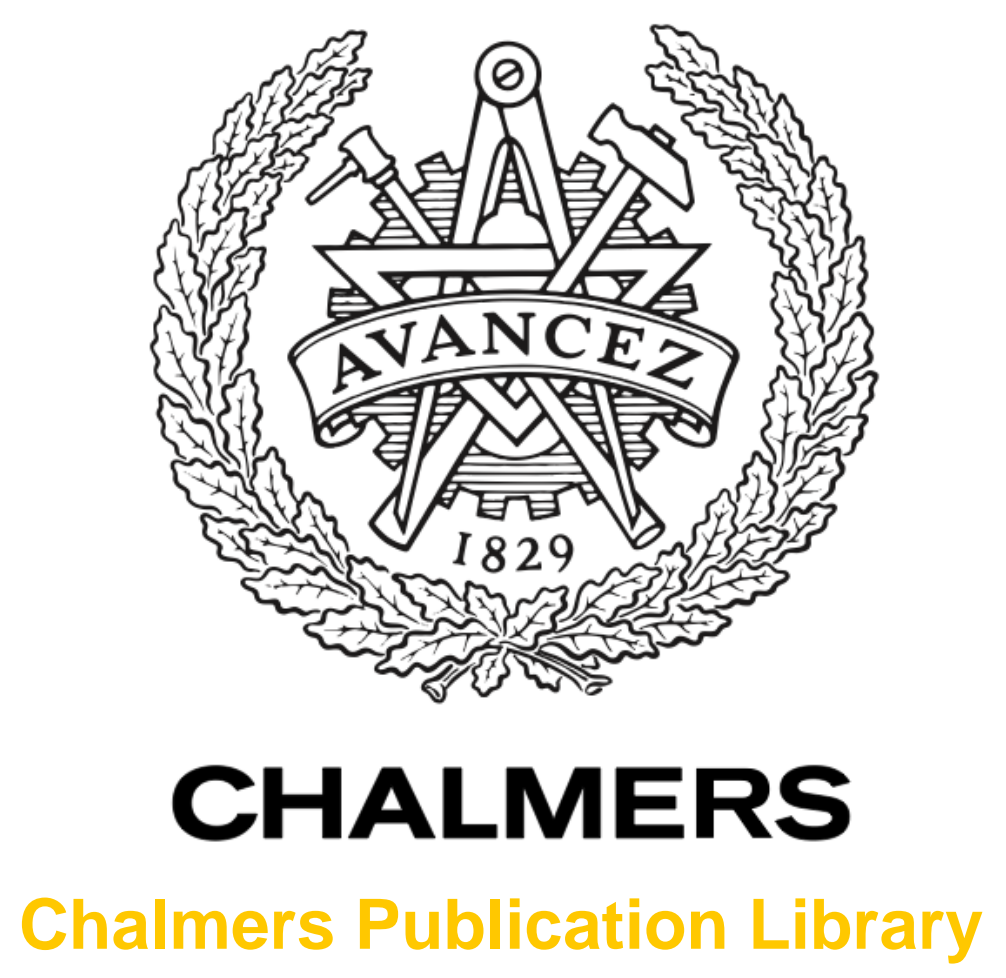

The impact of forecast information quality on supply chain performance

This document has been downloaded from Chalmers Publication Library (CPL). It is the author's version of a work that was accepted for publication in:

International Journal of Operations and Production Management

Citation for the published paper:

Forslund, H. ; Jonsson, P. (2007) "The impact of forecast information quality on supply chain performance". International Journal of Operations and Production Management, vol. 27(1), pp. 90-107.

Downloaded from: http://publications.lib.chalmers.se/publication/24402

Notice: Changes introduced as a result of publishing processes such as copy-editing and formatting may not be reflected in this document. For a definitive version of this work, please refer to the published source. Please note that access to the published version might require a subscription. 


\title{
THE IMPACT OF FORECAST INFORMATION QUALITY ON SUPPLY CHAIN PERFORMANCE
}

\author{
Helena Forslund \\ Växjö University \\ \& \\ Patrik Jonsson \\ Chalmers University of Technology
}

\begin{abstract}
Purpose: This paper describes the extent of supplier access to customer forecast information and the perceived quality of such information. It also explains the impact of forecast information access and forecast information quality on supply chain performance.
\end{abstract}

Methodology/approach: Forecast information quality is defined, and a measurement instrument is developed from theory. The analysis is based on a survey of the most important suppliers of 136 Swedish companies.

Findings: Findings show that a large proportion of the suppliers receive customer forecasts, but that the forecast information quality is lower further upstream in the supply chain and, in some variables, lower for make-to-order suppliers. The greatest information quality deficiency of the forecast was that it was considered unreliable. The only significant difference in supply chain performance found between make-to-stock suppliers with and without access to forecast was related to the use of safety stock in finished goods inventory.

Research limitations/implications: The study contains two types of conclusions, those developed from the conceptual discussion in the theoretical framework and those of the empirical study. In the theoretical framework, measurement instruments for forecast information quality and supply chain performance (corrective actions, preventive actions and customer service performance) were developed. The study identified several empirical relationships, but it was conducted on a samplewith large spread.

Practical implications: The understanding of the performance impact of forecast information quality. Forecast information quality shows quality deficiencies on all variables, which indicates room for improvement.

Originality/value of paper: Research on supply chain information quality as well as dyadic research approaches are rare.

Keywords: forecasts, information quality, supply chain, supply chain performance

Category: Research paper 
Full reference: Forslund, H. and Jonsson, P. 2007. The impact of forecast information quality on supply chain performance. International Journal of Operations and Production Management, 27(1): 90-107.

\section{INTRODUCTION}

Several studies and authors have emphasized the importance of sharing information between customers and suppliers in supply chains, especially point-of-sales (POS) and forecast data (e.g. Stank et al., 1996; Kelle and Akbulut, 2005; Christopher and Towill, 2000; Cachon and Fisher, 2000; Lee et al., 1997). However, while most studies discuss the general importance of having access to forecast information along the supply chain, they do not explain the impact of the available forecast information on supply chain performance, how available forecast information may have quality deficiencies, or how different information quality deficiencies may impact the usefulness of forecasts.

Supply chain performance is typically related to metrics reflecting cost, tied-up capital and customer service (Brewer and Speh, 2000). The supplier might need to use internal actions to compensate for poor customer service. Corrective actions, such as rush orders and over-time, are mainly related to costs for the supplier. Preventive actions, for example safety stocks and extra capacity, are mainly related to tied-up capital, but also to costs. The use of corrective and preventive actions could allow for good customer service performance even if the demand is uncertain, for example as a result of lack of access to customer forecasts. The importance of forecast data also depends on how it is used in the manufacturing planning and control processes. Long-term capacity forecasts may, for example, be considered most important for firms applying make-to-order strategies, while short-term material forecasts could be expected to be more important when applying make-to-stock strategies.

As a supplier, it may, however, not suffice to only have access to customers' forecasts. The interpretation and possible use of the forecast also depends on the quality of the forecast information, i.e. to what extent the supplier perceives the customer's forecast information as fulfilling expectations. The forecast could, for example, be available too late to be used in the planning process, be changed so often that the supplier does not trust it, exchanged in an inappropriate format, for example as a faxed document that needs much further processing before the supplier can make use of it, etc.

More rigorous empirical research on the performance effects of inter-organizational forecast information exchange is scarce. Several authors have emphasized the importance of conducting empirical studies on the performance impact of collaboration and the sharing of forecasts (e.g. McCarthy and Golicic, 2002). Consequently, we lack empirical studies on the performance impact of access to customer forecast and forecast information quality (hereafter denoted FIQ) discussed above. Empirical studies describing the present extent of forecast information sharing in supply chains are lacking. For example, to what extent is forecast information exchanged between companies? Does the exchange of forecast information and the quality of the forecast information differ further up-stream in the supply chain (e.g. between $1^{\text {st }}$ and $2^{\text {nd }}$ tier suppliers and between $2^{\text {nd }}$ and $3^{\text {rd }}$ tier suppliers) compared to down-stream (e.g. between retailers and OEMs and between OEMs and $1^{\text {st }}$ tier suppliers)? Does the exchange and perceived FIQ differ between companies with different supply strategies, for example between suppliers using make-to-stock (MTS) compared to make-to-order (MTO) strategies?

This paper deals with these research issues. It contains two sub-objectives. The first is to describe the extent of supplier access to customer forecast information and its perceived information quality. The second is to explain the performance impact of forecast information access and FIQ on supply chain performance. Not all types of forecast information are studied; only demand information important for supply chain performance. This means future demand expressed as product content, order quantity and delivery time. Firstly, the theoretical framework is described and hypotheses related to the second 
Full reference: Forslund, H. and Jonsson, P. 2007. The impact of forecast information quality on supply chain performance. International Journal of Operations and Production Management, 27(1): 90-107.

explanatory sub-objective are developed. Then, the data collection conducted through a mailed survey is discussed, and findings of the empirical analysis are presented and discussed.

\section{THEORETICAL FRAMEWORK AND HYPOTHESES GENERATION}

The issue of sharing forecasts in the supply chain has been studied from some different perspectives, for example, the collaborative planning forecasting and replenishment (CPFR) approach and modeling based approaches. No identified study has looked at the FIQ, but the concept of information quality has been studied in other disciplines. Here, a framework for describing and analyzing the FIQ is defined and developed. The definitions and measures of supply chain performance are also presented, along with a generation of hypotheses.

\section{Sharing forecast information}

A survey study with 177 responses from Swedish manufacturing companies in different industries (response rate of 38\%) with more than 100 employees, measuring the extent of forecast information sharing (Sandberg, 2005) shows that 95\% of the companies exchange forecast information with at least a monthly frequency. Aside from this study, no other broad descriptive study on forecast information sharing was identified. The literature on collaborative planning forecasting and replenishment (CPFR) discusses the issue of inter- and intra- organizational collaboration in the forecasting process. One important objective of forecasting collaboration is to develop a common plan for the single company and for the supply chain as a whole (Helms et al., 2000; McCarthy and Golicic, 2002). Most of the CPFR studies adopt a retailer perspective. Holmström et al. (2002) showed that the suppliers are more interested in sharing information and collaborating in the forecasting process than are the retailers. Their findings also indicated that suppliers gain most of the benefits of increased information sharing. A study by Småros (2003) on the forecasting collaboration in the grocery industry indicates that CPFRstyle intensive forecasting collaboration is not often feasible. Instead, the focus of the supplier-retailer collaboration should be on making useful demand information, such as POS and forecasts, available for the suppliers. This would allow suppliers to gain access to timely and accurate demand information from the retailers. This means that the retailers have the opportunity to delegate some of the planning and forecasting responsibility to motivated suppliers, and the suppliers acquire high information quality input to their planning processes. Even though CPFR shows promise for improving supply chain performance, the adoption rate has been slower than expected, especially in Europe. The single most important obstacle was claimed to be the customer's lack of forecasting processes and resources (ibid). The CPFR related studies emphasise the importance and performance potential of forecast exchange, especially for the supplier in a dyadic supplier - customer relationship. However, the correlations between forecast exchange and performance are not studied.

There are also some modeling based studies on forecasting exchange. Cachon and Fisher (2000) recognized that the performance effects of sharing forecast information are low when demand is predictable, as compared to situations where demand is unpredictable. Zhao (2002) showed that the supplier capacity constraints impact the possibility of the supplier to successfully use the customer forecast. Aviv (2001) found through a simulation study that collaborative forecasting results in lower costs as compared to local forecasting, i.e. a situation where each individual actor develops its own forecast. A number of studies indicate the importance of sharing forecast and POS data in order to decrease the bullwhip effect (e.g. Lee et al., 1997). Consequently, studies show that a forecast received from a customer company could result in positive results but that the effects are dependent on the conditions on hand, i.e. how the forecast is used in the supplier's planning processes. It could, for 
Full reference: Forslund, H. and Jonsson, P. 2007. The impact of forecast information quality on supply chain performance. International Journal of Operations and Production Management, 27(1): 90-107.

example, be expected that forecast exchange is more important if using MTS strategies compared to MTO. Previous studies have, however, not compared the effects of forecast exchange between different types of companies or manufacturing strategies, but rather focused on specific situations when studying the performance effects of forecasting.

\section{Forecast information quality}

It does not suffice to only have access to customers' forecasts. The interpretation and possible use of the forecast data depend on the quality of forecast information. Information quality cannot be measured objectively; instead, it must be judged by the receiving supplier (Forslund, 2004). As defined here, FIQ is not equal to forecast error, measured as the deviation between actual demand and forecast and expressed as mean absolute deviation or mean error. FIQ is discussed and defined in the two following sections.

More exactly, some features of FIQ are critical. Although no study of measuring FIQ was found, there are studies on information quality in general (e.g. English, 1999 and Lee et al., 2002) and some on order information quality. Petersen (1999) measured information quality in terms of if it was current, accurate, complete, compatible or convenient to access. Whipple et al. (2002) studied operational information exchange in alliances. They did not use the construct information quality, but measured the value of information deployed as timely and accurate. English (1999) and Lindau and Lumsden (1995) stated that the information quality dimensions could be derived from the seven rights of logistics, i.e. the right place, time, quantity, quality, price, condition and customer (e.g. Stock and Lambert, 1992). The seven rights origin from Weld's (1916) five rights of a logistics system to supply the right product, at the right place, at the right time, in the right condition for the right cost to the customers consuming the product. Lindau and Lumsden (1995) focused on three information quality dimensions derived from the rights. With correct information they meant the right information in the right condition. With timely information they meant information received at the right time, to the right receiver and to the right place. Complete information was related to the right quantity. Moberg et al. (2002) stated that information has little value if it has poor reliability and validity. They further discussed accuracy, timeliness and proper formatting as important qualities of information, but without defining the dimensions. Closs et al. (1997) evaluated information systems with dimensions regarding both information in itself and the information system. The dimensions regarding information were timeliness, accuracy, availability and formatted to facilitate usage. Clikeman (1999) says that companies that have reengineered their production processes have identified four dimensions of quality: relevance, reliability, timeliness and cost. The same dimensions apply to information.

Most information quality related studies do not focus on forecast information used in manufacturing or supply chain planning. Therefore, a "transition" from these general studies towards forecast information quality variables is necessary. We here define and describe forecast information quality with the four information quality variables in time, accurate, convenient to access and reliable. Forecast information being in time means that it is in the agreed time, when the information customer wants it. It is also concurrent to the situation, i.e. that the state of information used for decision making corresponds to the situation, so the data represented is not time-phased with regard to when it was registered and presented. Accuracy concerns the degree of obvious mistakes in the information. Forecast information coming from a customer might be impaired by obvious mistakes, which must be corrected before entered into the supplier's planning system. Convenient to access, deals with the ease of accessing the data without further processing. Processing could mean adapting an item code or entering it manually into the supplier's planning system. The forth variable, reliability refers to the 
Full reference: Forslund, H. and Jonsson, P. 2007. The impact of forecast information quality on supply chain performance. International Journal of Operations and Production Management, 27(1): 90-107.

probability that a forecast will remain unchanged. Unreliable information means uncertainty to the supplying company, which has to be absorbed by safety mechanisms.

\section{Supply chain performance}

Some of the modeling based studies on sharing forecasts in supply chains link forecast exchange to supply chain performance. Lee et al. (1997) and several others have shown that the demand variability can be amplified upstream in the supply chain when not sharing accurate forecasts with the suppliers. Zhao et al. (2002) concluded that the value of information sharing is significantly influenced by the demand pattern, forecasting model used and the supplier's capacity tightness, i.e. its total production capacity in relationship to the total demand to be satisfied, but that the suppliers usually can improve their total costs and customer service dramatically through information sharing under all conditions. Aviv (2001) compared local forecasting with exchange of collaborative forecasts and concluded that the supply chain costs were reduced when exchanging forecast information. Also several CPFR related pilot studies (Fliedner, 2003) include performance improvement figures, such as higher order fill rates, lower product inventories, obsolescence and deterioration for the supplier. McCarthy and Golicic (2002) made an exploratory study of collaborative forecasting, which was defined as a long-term relationship among organizations actively working together with forecasting (Mentzer et al., 2000), and identified substantial impact on supply chain performance. Improvement in customer service performance, such as shorter lead times, improved inventory availability and better response to fluctuations in demand, was found. Furthermore, improvements in cost and capital were found which could be related to reductions in safety stock. A survey by Frohlich and Westbrook (2001) showed that firms with higher levels of supplier and customer integration also demonstrated the highest supply chain performance. Frohlich and Westbrook did not explicitly study sharing forecasts, but sharing production plans was one of the integrative activities studied. Another study (Thonemann, 2002) that focuses on supply chain exchange of information also identified significant cost savings for the supplier. Consequently, numerous studies emphasise the positive impact of forecast information exchange, but there is a lack of studies that empirically explain the performance impact of forecast exchange.

Generation of the conceptual model and hypotheses

Figure 1 describes the variables studied in the two sub-objectives of the paper. The first sub-objective describes the state-of-the-art access of customer's demand forecast and its perceived information quality at suppliers. The access and perceived information quality is compared between companies applying make-to-stock and make-to-order strategies, and between suppliers in different supply chain tiers. Studies show that the level of supply chain integration is more developed further down-stream, i.e. closer to the end customer (e.g. Mattsson, 2002). Here, access to customer forecasts and perceived FIQ are compared between $2^{\text {nd }}$ tier suppliers, $1^{\text {st }}$ tier suppliers and OEMs. 
Full reference: Forslund, H. and Jonsson, P. 2007. The impact of forecast information quality on supply chain performance. International Journal of Operations and Production Management, 27(1): 90-107.

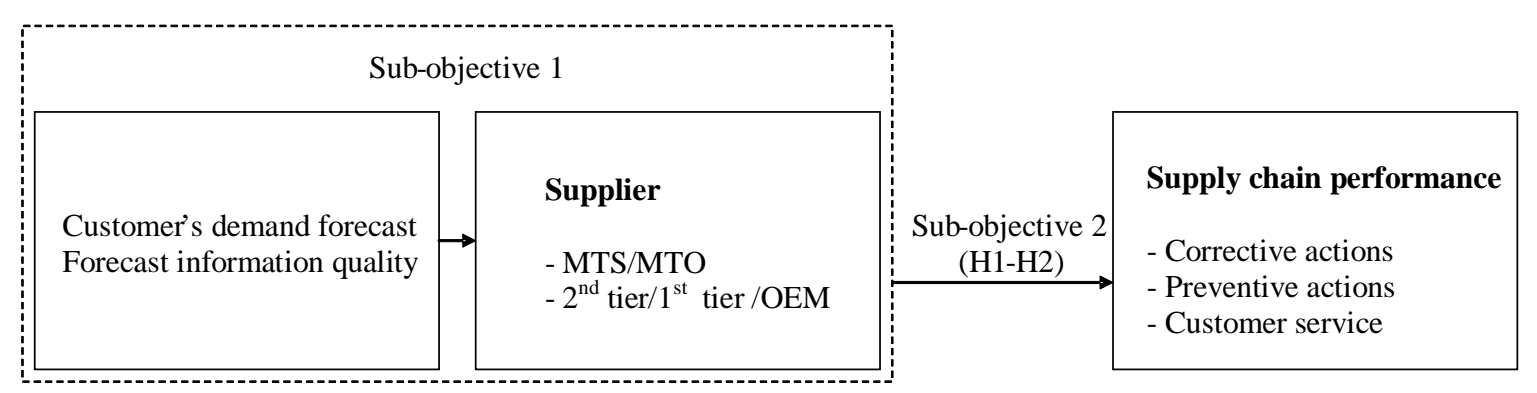

Figure 1. A conceptual model of the study

To analyze sub-objective two about the performance impact of customer forecast access and perceived FIQ, two hypotheses could be derived from the above discussion in the theoretical framework. The first hypothesis deals with the performance impact of forecast access.

Supply chain performance could be related to customer service, corrective actions and preventive actions. Customer service goals could be fulfilled by using corrective actions. These are the supplier's unplanned actions to correct deficiencies occurred in customer service related to a specific customer order. These actions are such that result in "increased" costs. Based on Lindau and Lumsden (1993) and Mattsson (2002) the following corrective actions are defined: subcontracting, expediting, part delivery, re-scheduling, reservation breaking, overtime and express transports. Using preventive actions or safety mechanisms can also deal with planning uncertainty. Preventive actions are of a character that results in "increased" tied-up capital and costs. Based on Lindau and Lumsden (1993) and Fahlén (1997) the following preventive actions are defined: safety stocks in raw material and finished goods inventories, safety capacity, safety lead times and over-planning. These are the supplier's planned actions to prevent future deficiencies in customer service. The use of corrective and preventive actions allows for good customer service performance even though the planning environment is uncertain, for example as a result of lacking or quality deficient forecast information. Consequently, the combined effect of costs and tied-up capital, related to corrective and preventive actions, and customer service make up the supply chain performance.

It can be expected that a history of forecasts makes it possible for the supplier to act correctively and preventively when deficiencies in supply chain performance may occur. However, if the environment is very uncertain or the costs and cash-flow effects of the corrective and preventive actions are very high, the customer service performance can still be expected to be lower in firms without access to customer forecasts compared to firms with access to customer forecasts. Obviously, it is not possible to explain the impact of forecast exchange on any of the individual performance variables corrective actions, preventive actions and customer service. In accordance with the above discussion about the expected supply chain performance impact of forecast exchange (e.g. Fliedner, 2003; Thonemann, 2002; Aviv, 2001; Zhao et al., 2002; McCarthy and Golicic, 2002) we use the combined effect of corrective actions, preventive actions and customer service when defining supply chain performance, and formulate the first hypothesis in the following way:

H1: Supply chain performance is higher for suppliers with access to customer forecasts compared to suppliers without access to forecasts. 
Full reference: Forslund, H. and Jonsson, P. 2007. The impact of forecast information quality on supply chain performance. International Journal of Operations and Production Management, 27(1): 90-107.

Hypothesis two deals with the performance impact of the FIQ. Several studies have emphasized the expected supply chain performance impact of exchanging forecasts as discussed when deriving hypothesis one. No identified study has, however, studied the performance impact of FIQ. Keebler et al. (1999) and McCarthy and Golicic (2002) concluded that accurate forecast information significantly improves efficiency but they did not define accuracy and did not study any other FIQ dimension. The only FIQ related dimension identified in previous research is the forecast error, defined as the deviation between forecast and actual demand. It has a direct impact on the customer service and safety stock levels (e.g. Vollmann et al., 2005). In this paper the forecast error is, however, not defined as a FIQ dimension. Instead, we use the four variables in time, accurate, convenient to access and reliable. A common reasoning is that delayed, inaccurate and unreliable forecasts create demand uncertainty upstream the supply chain and therefore impact the supply chain performance in negative ways (e.g. Lee et al., 1997; van der Vorst and Beulens, 2002). A forecast could arrive in time, be formally correct and reliable but still not useful for the user because of its inconvenience to access. The convenience to access is especially important when the forecast information is processed manually, for example stored on paper print outs or Excel sheets that are not automatically readable by the receiver's ERP system. In such situations, low level of convenience to access could be expected to be both time consuming and result in data registration errors (e.g. Lindau, 1995). Thus, the convenience to accessing forecast information could also be expected to impact the performance. We could, consequently, expect that improved FIQ impact the use of corrective actions, preventive actions and customer service in a way that have positive impact on the combined supply chain performance. This results in the following formulation of hypothesis two:

H2: Supply chain performance is positively correlated with forecast information quality.

\section{METHODOLOGY}

A dyadic research approach was necessary to describe the cooperation between suppliers and certain customers. Surveys were selected as the empirical data generating method, as recommended by McCarthy and Golicic (2002). Surveys fit into a desire to conduct objective, deductive research with little interviewer bias. A larger number of respondents can be addressed with surveys, which makes it possible to use statistical analysis techniques such as factor analysis (Hair et al., 1998).

\section{Survey instrument}

Tables I-IV show the definitions and operationalisations of the variables related to forecast information quality, corrective actions, preventive actions and customer service. The forecast information quality variables are derived from the theoretical framework on forecast information quality (e.g. English, 1999, Petersen, 1999 and Moberg et al., 2002). The corrective and preventive action variables are based on the works of Lindau and Lumsden (1993), Ericsson (1997), Fahlén (1997) and Mattsson (2002). The customer service variables are based on Stock and Lambert (1992) and Mattsson (2002). Likert scales from 1 to 7 were used for all these variables, measured on ordinal scales. The questions asked and definitions of scales for the respective variable are included in Tables I-IV. 
Full reference: Forslund, H. and Jonsson, P. 2007. The impact of forecast information quality on supply chain performance. International Journal of Operations and Production Management, 27(1): 90-107.

Table I. Variables of forecast information quality

\begin{tabular}{|l|l|l|}
\hline \multicolumn{2}{|l|}{$\begin{array}{l}\text { Question: “Forecasts received from the customer are a) in time, b) accurate, c) convenient to access, d) reliable” } \\
\text { Scale: 7 point Likert scale from 1 [strongly disagree] to 7 [strongly agree] }\end{array}$} \\
\hline Variable & Definition & Source (order information quality) \\
\hline In time & $\begin{array}{l}\text { Arriving in the agreed time - within the supplier's } \\
\text { planning horizon }\end{array}$ & Lindau (1995), Clikeman (1999), English (1999) \\
\hline Accurate & Free from obvious mistakes & Petersen (1999), Whipple et al. (2002), English (1999) \\
\hline Convenient to access & Easy access without further processing & $\begin{array}{l}\text { Petersen (1999), English (1999), Closs et al. (1997), } \\
\text { Moberg et al. (2002), Keebler et al. (1999) }\end{array}$ \\
\hline Reliable & The probability that a forecast remains unchanged & Mattsson (2002), Moberg et al. (2002) \\
\hline
\end{tabular}

The average of the four information quality variables was defined and used as an overall FIQ index (SIQFOR). This scale was considered possessing both content and construct validity. Content validity was reached as the scale was based on extensive literature reviews and by conducting pretests by academic colleagues and practitioners (Flynn et al., 1990). Construct validity was ensured, as all Eigenvalues were larger than one and individual factor loadings exceed 0.40, in fact they exceed 0.80 . The scale was further considered reliable according to the Cronbach's Alpha value of 0.87. An Alpha value of 0.70 is considered acceptable for a scale, and for new scales 0.60 is acceptable (Hair et al., 1998).

Table II. Variables of corrective actions

\begin{tabular}{|c|c|c|}
\hline \multicolumn{3}{|c|}{$\begin{array}{l}\text { Question: "To perform the promised customer service we use a) subcontracti } \\
\text { reservation breaking, f) overtime, g) express transports" } \\
\text { Scale: } 7 \text { point Likert scale from } 1 \text { [to very low extent] to } 7 \text { [to very high extent] }\end{array}$} \\
\hline Corrective action variable & Definition & Source \\
\hline Subcontracting & Short-term, as a result of unforeseen overload & Lindau and Lumsden (1993) \\
\hline Expediting & $\begin{array}{l}\text { Finding and rushing “hot” jobs through } \\
\text { production }\end{array}$ & Lindau and Lumsden (1993) \\
\hline Part delivery & Smaller batches in production or delivery & Lindau and Lumsden (1993) \\
\hline Re-scheduling & Re-plan & Lindau and Lumsden (1993), Fahlén (1997) \\
\hline Reservation breaking & $\begin{array}{l}\text { Already reserved material (for another customer) } \\
\text { is used earlier }\end{array}$ & Lindau, Lumsden (1993) \\
\hline Overtime & Short-term & Ericsson (1997), Mattsson (2002) \\
\hline Express transports & $\begin{array}{l}\text { A faster and more expensive means of } \\
\text { transportation is used to speed up a delivery }\end{array}$ & Mattsson (2002) \\
\hline
\end{tabular}

Table III. Variables of preventive actions

\begin{tabular}{|l|l|l|}
\hline $\begin{array}{l}\text { Question: “To perform the promised customer service we use a) safety stock in raw material inventory, b) safety stock in finished goods } \\
\text { inventory, c) safety capacity, d) safety lead time, e) over-planning” } \\
\text { Scale: 7 point Likert scale from 1 [to very low extent] to 7 [to very high extent] }\end{array}$ \\
\hline Preventive action variable & Definition & Source \\
\hline $\begin{array}{l}\text { Safety stock in raw material } \\
\text { inventory }\end{array}$ & $\begin{array}{l}\text { Stock kept as a reserve to guard against material } \\
\text { shortage because of uncertainties in supply, demand } \\
\text { and lead time }\end{array}$ & Lindau and Lumsden (1993), Fahlén (1997) \\
\hline $\begin{array}{l}\text { Safety stock in finished goods } \\
\text { inventory }\end{array}$ & $\begin{array}{l}\text { Stock kept as a reserve to guard against material } \\
\text { shortage because of uncertainties }\end{array}$ & Lindau and Lumsden (1993), Fahlén (1997) \\
\hline Safety capacity & $\begin{array}{l}\text { The reservation of extra capacity, i.e. plan with under- } \\
\text { capacity utilization to protect against unforeseen events }\end{array}$ & Lindau and Lumsden (1993), Fahlén (1997) \\
\hline Safety lead time & $\begin{array}{l}\text { The order starts earlier to be finished before its due } \\
\text { date }\end{array}$ & Lindau and Lumsden (1993), Fahlén (1997) \\
\hline $\begin{array}{l}\text { Over-planning (demand } \\
\text { hedges) }\end{array}$ & $\begin{array}{l}\text { Instead of safety stock or safety lead time, a larger } \\
\text { quantity than known demand is planned }\end{array}$ & Lindau and Lumsden (1993) \\
\hline
\end{tabular}


Full reference: Forslund, H. and Jonsson, P. 2007. The impact of forecast information quality on supply chain performance. International Journal of Operations and Production Management, 27(1): 90-107.

Table IV. Variables of customer service performance

\begin{tabular}{|l|l|}
\hline $\begin{array}{l}\text { Question: “For our most important customer we perform perfect a) promised lead time, b) on-time delivery, c) use rush orders when } \\
\text { needed, d) promised inventory availability, e) accurate orders, f) availability of delay information” } \\
\text { Scale: 7 point Likert scale from 1 [strongly disagree] to 7 [strongly agree] }\end{array}$ \\
\hline Customer service performance variable & Source \\
\hline Promised lead time (the time between placing and receiving an order) & Stock and Lambert (1992) \\
\hline On-time delivery (orders are delivered at agreed time) & Stock and Lambert (1992) \\
\hline Rush orders when needed & Stock and Lambert (1992) \\
\hline Promised inventory availability (to what degree orders can be delivered from inventory) & Stock and Lambert (1992) \\
\hline Accurate orders (the right number of items ordered arrives) & Stock and Lambert (1992) \\
\hline Availability of delay information & Stock and Lambert (1992), Mattsson (2002) \\
\hline
\end{tabular}

Data collection

One customer and one supplier survey questionnaire were developed. To obtain the view of customers, purchasing managers were addressed. When Swedish companies with 100 or more employees were selected in four industries (fabricated metal industry, machinery, electronic equipment and automotive), 432 purchasing managers were found. It was then decided to address the entire population. Customers answered questions related to their most important Swedish supplier. 171 usable responses were received, corresponding to a response rate of 39.6\%. 149 customers provided contact information to the addressed supplier.

149 supplier questionnaires were mailed to those suppliers, covering questions related to customer service performance, the use of preventive and corrective actions, and perceived FIQ from that customer. 136 supplier responses were returned. This corresponds to a response rate in the supplier survey of $91.3 \%$ (136/149). The distribution by industry and company size varied. Altogether, ten different industries were represented among the supplier responses, compared to four among the customers. Among these 136 responses, suppliers representing wholesaling companies were subtracted, leaving 121 manufacturing suppliers. Hence the study covers 121 matched customer-supplier dyads.

\section{Reliability and validity}

Reliability was ensured by using a standardized, structured survey instrument with instructions for the respondents. Testing non-response bias is a part of a reliability assessment. In the customer survey, chi square statistics revealed no significant differences at the $\mathrm{p}<0.05$ level between respondents and nonrespondents regarding industry and company size. Due to the fact that the population in the supplier survey was hard to define, and to the prevailing high response rate, no analysis of non-response bias was undertaken in the supplier survey. Inter-item reliability for a scale is another part of a reliability analysis. This analysis was performed in connection to the survey instrument. As the study's reliability was acceptable, an important prerequisite for validity was obtained. Validity was increased as scales were drawn from directly from existing sources and as pretests were conducted, as recommended by Flynn et al. (1990). Altogether, the study’s reliability and validity was assessed acceptable.

\section{FINDINGS}

State-of-the-art description of forecast access and its perceived information quality

In 105 of the 121 customer supplier dyads studied (87\%), suppliers were receiving forecast information. 69 of the 80 (86\%) MTS suppliers received forecast information, as compared to 35 of the 41 (85\%) MTO suppliers. No significant difference in forecast access could be identified when MTS 
Full reference: Forslund, H. and Jonsson, P. 2007. The impact of forecast information quality on supply chain performance. International Journal of Operations and Production Management, 27(1): 90-107.

and MTO suppliers were separated. Forecast access was also studied between $2^{\text {nd }}$ tier, $1^{\text {st }}$ tier and OEMs. 19 of the 20 OEMs (95\%) received customer forecasts. This is a larger proportion than for the 2nd tier suppliers, where 20 of 24 suppliers (83\%) received forecast information, and for the 1st tier suppliers, where 65 of 77 suppliers (84\%) received forecast information. It was not possible to conduct significance tests (Chi square) on the difference in forecast access between the groups due to the fact that some cells contained too few observations. The average perceived FIQ by suppliers for each variable is shown in Table $\mathrm{V}$, together with the results of an ANOVA test (with Bonferroni's pair-wise comparisons) for differences between the variables. The index SIQFOR is also shown in Table V.

Table V. Perceived forecast information quality by all suppliers

\begin{tabular}{|l|l|l|l|}
\hline Forecast information quality variable & $\mathrm{N}$ & Mean (st dev) & Significant difference with variable* \\
\hline In time & 105 & $5.43(1.71)$ & $\begin{array}{l}\text { Accurate } \\
\text { Reliable }\end{array}$ \\
\hline Accurate & 104 & $5.86(1.52)$ & $\begin{array}{l}\text { In time } \\
\text { Convenient to access } \\
\text { Reliable }\end{array}$ \\
\hline Convenient to access & 102 & $5.37(1.75)$ & Accurate \\
\hline Reliable & 103 & $4.77(1.84)$ & $\begin{array}{l}\text { In time } \\
\text { Accurate }\end{array}$ \\
\hline SIQFOR (index) & & $5.34(1.47)$ & \\
\hline
\end{tabular}

Note: ANOVA with F-statistics: 15.02. *Shows variables with significant different mean using Bonferroni’s tests.

The reliable variable is significantly lower (i.e. the quality deficiency is higher) than in time and accurate. The accurate variable is significantly higher than the other variables. In Tables VI and VII the perceived FIQ is compared between MTS and MTO firms and between $2^{\text {nd }}$ tier and $1^{\text {st }}$ tier suppliers and OEMs. No significant difference was identified between MTS and MTO firms except for in time $(p<0.10)$. Most quality variables were lower (i.e. the quality deficiency was higher) for the $2^{\text {nd }}$ tier suppliers as compared to the $1^{\text {st }}$ tier suppliers and the OEMs, but not significantly.

Table VI. Perceived forecast information quality by MTS/MTO suppliers

\begin{tabular}{|l|l|l|l|l|l|l|}
\hline Forecast information quality variable & n MTS & Mean (st dev) & n MTO & Mean (st dev) & Mean diff & T value \\
\hline In time & 69 & $5.65(1.54)$ & 35 & $4.97(1.96)$ & 0.68 & $1.94^{*}$ \\
\hline Accurate & 69 & $5.97(1.37)$ & 34 & $5.65(1.79)$ & 0.32 & 1.02 \\
\hline Convenient to access & 69 & $5.42(1.78)$ & 33 & $5.30(1.74)$ & 0.12 & 0.31 \\
\hline Reliable & 68 & $4.79(1.78)$ & 34 & $4.79(1.95)$ & 0.00 & 0.00 \\
\hline SIQFOR (index) & & $5.46(1.36)$ & & $5.12(1.68)$ & 0.34 & 1.12 \\
\hline
\end{tabular}

* sig at the $\mathrm{p}<0.10$ level

Table VII. Perceived forecast information quality by $2^{\text {nd }}$ tier $/ 1^{\text {st }}$ tier/OEM suppliers

\begin{tabular}{|c|c|c|c|c|c|c|c|}
\hline $\begin{array}{l}\text { Forecast information } \\
\text { quality variable }\end{array}$ & n $2^{\text {nd }}$ tier & Mean (st dev) & n $1^{\text {st }}$ tier & Mean (std dev) & n OEM & Mean (std dev) & F-stats \\
\hline Accurate & 19 & $5.58(1.71)$ & 65 & $5.98(1.45)$ & 19 & $5.74(1.59)$ & 0.54 \\
\hline Reliable & 19 & $4.26(1.85)$ & 64 & $4.88(1.83)$ & 19 & $5.05(1.78)$ & 1.17 \\
\hline SIQFOR (index) & & $4.89(1.50)$ & & $5.44(1.86)$ & & $5.51(1.58)$ & \\
\hline
\end{tabular}


Full reference: Forslund, H. and Jonsson, P. 2007. The impact of forecast information quality on supply chain performance. International Journal of Operations and Production Management, 27(1): 90-107.

The performance impact of forecast information access and forecast information quality In order to test hypotheses one and two in a group of companies with somewhat homogeneous manufacturing strategies, they were only tested among the MTS suppliers. T-tests were used to analyze the significant differences in supply chain performance between suppliers with access to customer forecasts and suppliers without access to forecasts (H1). Tables VIII and IX present the findings.

The findings of $\mathrm{H1}$ (Table VIII) indicate that suppliers without access to forecasts use less corrective actions than suppliers with access to forecasts. However, the differences are not significant for any variable. There are also indications that suppliers use preventive actions to larger extents than corrective actions. Especially extensive is the use of safety stock in raw material and finished goods inventory. Suppliers without access to a forecast use safety stock more than suppliers with access to a forecast. The difference is significant $(\mathrm{p}<0.05)$ for the use of safety stock in finished goods inventory and significant $(\mathrm{p}<0.1)$ for the use of safety stock in raw material inventory. For the remaining preventive actions there are no significant differences. No significant difference in customer service performance between suppliers with and without access to forecasts was found on any variable. An explanation to the finding that only preventive actions are used to significantly larger extent and that the extent of using corrective actions and customer service are not significantly different between suppliers receiving forecast information and those not receiving forecast information may be the high overall customer service requirements.

Table VIII. Result from testing H1

\begin{tabular}{|l|l|l|}
\hline Corrective action variable & Mean no forecast-forecast = mean difference & T value \\
\hline Subcontracting & $1.71-1.98=-0.27$ & -0.47 \\
\hline Expediting & $3.63-4.26=-0.63$ & -0.97 \\
\hline Part delivery & $2.90-3.17=-0.27$ & -0.45 \\
\hline Re-scheduling & $3.10-4.06=-0.96$ & -1.76 \\
\hline Reservation breaking & $2.00-2.35=-0.35$ & -0.74 \\
\hline Overtime & $3.20-3.65=-0.45$ & -0.73 \\
\hline Express transports & $2.60-2.74=-0.14$ & -0.24 \\
\hline Preventive action variable & Mean no forecast-forecast = mean difference & T value \\
\hline Safety stock in raw material inventory & $6.10-4.96=1.14$ & 1.86 \\
\hline Safety stock in finished goods inventory & $5.50-3.97=1.53$ & $2.21^{*}$ \\
\hline Safety capacity & $2.50-3.40=-0.9$ & -1.44 \\
\hline Safety lead time & $3.00-3.37=-0.37$ & -0.55 \\
\hline Over-planning & $2.00-3.03=-1.03$ & -1.54 \\
\hline Customer service performance variable & Mean no forecast-forecast = mean difference & T value \\
\hline Promised lead time & $6.36-6.03=0.33$ & 1.09 \\
\hline On-time delivery & $6.36-5.99=0.38$ & 1.25 \\
\hline Rush orders when needed & $6.18-6.11=0.07$ & 0.21 \\
\hline Promised inventory availability & $6.00-5.69=0.31$ & 0.69 \\
\hline Accurate orders & $6.27-6.46=-0.18$ & -0.80 \\
\hline Availability of delay information & $5.91-5.88=0.03$ & 0.07 \\
\hline
\end{tabular}

* sig at the $\mathrm{p}<0.05$ level

To test hypothesis two, Pearson correlation was used to analyze the correlation between supply chain performance and FIQ. The hypothesis could not be verified. Table IX shows that the only significant correlation existed for the customer service variable "rush orders when needed" and SIQFOR. 
Full reference: Forslund, H. and Jonsson, P. 2007. The impact of forecast information quality on supply chain performance. International Journal of Operations and Production Management, 27(1): 90-107.

Table IX. Result from testing $\mathrm{H} 2$

\begin{tabular}{|l|l|l|}
\hline Corrective action variable & Pearson correlation with SIQFOR & Sig (two-tailed) \\
\hline Subcontracting & -0.05 & 0.72 \\
\hline Expediting & 0.11 & 0.35 \\
\hline Part delivery & -0.12 & 0.30 \\
\hline Re-scheduling & 0.03 & 0.83 \\
\hline Reservation breaking & 0.21 & 0.10 \\
\hline Overtime & -0.02 & 0.87 \\
\hline Express transports & -0.05 & 0.67 \\
\hline Preventive action variable & Pearson correlation with SIQFOR & Sig (two-tailed) \\
\hline Safety stock in raw material inventory & 0.11 & 0.34 \\
\hline Safety stock in finished goods inventory & 0.02 & 0.88 \\
\hline Safety capacity & -0.04 & 0.78 \\
\hline Safety lead time & -0.12 & 0.33 \\
\hline Over-planning & -0.04 & 0.75 \\
\hline Customer service performance variable & Pearson correlation with SIQFOR & Sig (two-tailed) \\
\hline Promised lead time & 0.13 & 0.28 \\
\hline On-time delivery & 0.05 & 0.67 \\
\hline Rush orders when needed & 0.31 & $0.01^{* *}$ \\
\hline Promised inventory availability & 0.12 & 0.32 \\
\hline Accurate orders & 0.03 & 0.79 \\
\hline Availability of delay information & -0.11 & 0.33 \\
\hline$* *$ sig at the p<0.01 level & \\
\hline
\end{tabular}

** sig at the $\mathrm{p}<0.01$ level

\section{DISCUSSION}

A large proportion of the suppliers were receiving customer forecasts. One reason for this may be that the suppliers are all rated as the customers' most important supplier, and a deeper cooperation than the average can be expected. If any supplier had been chosen the proportion might have been lower. Still the extent of exchange identified in this study is similar to other studies (e.g. Sandberg, 2005). The forecasting type or how frequently forecasts are exchanged were not studied either.

Quality deficiencies were found for all FIQ variables. The accurate variable is however significantly higher than the other variables, which implies that suppliers perceive that forecasts are rather free from obvious mistakes. This could be expected since important and established customer/supplier dyads are studied, and accuracy should have been discussed and dealt with. Reliability was rated significantly lower. The reliability of forecast information quality, i.e. the probability that a forecast is being unchanged, could be interpreted as the forecast error. Convenient to access and in time were also rated significantly lower. No identified study measured the information quality of forecasts. However, Closs et al. (1997) found convenient to access to be the variable with the lowest quality when measuring order information quality. This result might be related to how forecasts are communicated between customer and supplier. Forecasts might arrive on fax or in an Excel spread sheet, which implies that the customer needs to do a considerable amount of work to be able to use it. The aggregation level might also be unadapted to the customer's needs, for example, be on product group level where a product level would have been preferred.

The study indicated that there are large quality deficiencies among $2^{\text {nd }}$ tier suppliers as compared to $1^{\text {st }}$ tier suppliers and OEMs. However, the differences are not significant, partly due to the low number of OEMs and 2nd tier suppliers in the study. The quality variable in time was considered significantly lower for MTO compared to MTS suppliers. Forecasts are important input to the capacity planning in 
Full reference: Forslund, H. and Jonsson, P. 2007. The impact of forecast information quality on supply chain performance. International Journal of Operations and Production Management, 27(1): 90-107.

MTO companies and to the priority planning and execution in MTS companies. The lack of timely forecasts in MTO companies may, consequently, impact their capacity planning processes.

When testing $\mathrm{H} 1$, the only significant difference in supply chain performance between suppliers with and without access to forecast, was related to the use of safety stock in finished goods inventory. The customer service did not differ between the groups. Consequently, it seems to be necessary for all suppliers to perform high customer service. Here, they were all selected as the customers' most important supplier, which may further explain this focus. The conclusion that exchange of forecast information has positive performance impact is logical and in line with previous research (e.g. Fliedner, 2003; Thonemann, 2002; Aviv, 2001; Zhao et al., 2002; McCarthy and Golicic, 2002).

H2 was not verified. Why? Does FIQ not matter? This study was characterized by a large spread in the supplier sample; it consisted of both large and small suppliers in ten industries. It is possible that customer demand is predictable, an aspect that was not measured. Information quality is perhaps not so important when demand is predictable, as claimed by Cachon and Fisher (2000). Småros (2003) found that the single most important obstacle for collaborative forecasting was the customer's lack of forecasting processes. Research on the managerial side of forecasting, how forecasts are handled, was called for by Wacker and Lummus (2002).

Our study has not revealed information about the customer's own forecasting process. It is also worth repeating that this study was not focused on collaborative forecasting, but merely asked if forecast information was transferred or not. This study was a first attempt to measure the performance impact of FIQ but it was limited, especially in terms of the number of surveyed companies of similar types.

The study reveals the need for more studies in the area of forecast information quality. One area of research deals with explaining the causes for high or low perceived FIQ. Another is about the performance impact of FIQ. More detailed research questions of the two areas could be related to the conditions of the actual demand pattern and the processes related to actual forecasting at the customer, transmission of the information from the customer to the supplier, registration of the data at the supplier and the characteristics of the processes and actors using the forecast data. The following are issues for such further studies:

- Customer's demand pattern: The predictability of the demand influences the need for forecasts and, consequently, impacts the need for exchange and the potential performance impact of forecast exchange and its information quality. Forecast information could thus be expected to have different performance impact in different demand situations.

- Customer's forecast design: The customer's decisions of how to present the forecasts should have an information quality impact (e.g. the aggregation level and the exchange frequency). Different forecast information quality could, for example, be expected between situations where the supplier is involved in the design or if a CPFR-style collaboration is established compared to if that is not the case.

- Customer's forecasting process: The way the process of generating forecasts is performed and how well it is functioning should impact the exchange of forecasts and the perceived information quality. Differences could, for example, be expected between situations where the supplier, in a consensus forecasting manner, is involved in the data collection and 
Full reference: Forslund, H. and Jonsson, P. 2007. The impact of forecast information quality on supply chain performance. International Journal of Operations and Production Management, 27(1): 90-107.

manual evaluation and adjustment of forecasts or if a CPFR-style collaboration is established compared to if that is not the case.

- Customer's forecast transferring method: The interface between customer and supplier, for example, the use of information and communication technology, could impact the exchange frequency and the information quality. It could, for example, be expected that using EDI or web-EDI result in exchange of more timely but also more accurate forecast.

- Registration of customer forecasts at the suppliers: The registration of received forecasts could impact the information quality, for example, if it is automatically registered through EDI, electronically transferred from an Excel sheet or manually typed into the ERP system.

- Supplier's manufacturing process where the forecast is used: The forecast could be used in situations with different supply strategies (e.g. MTS or MTO), in different planning processes (e.g. with a priority or capacity planning perspective), on different levels of detail (e.g. master planning or more detailed material planning based on material requirements planning or re-order point systems), and on different planning horizons. The different users place different requirements on the forecast and could consequently interpret the same forecast as having different information quality.

- Who is the forecast information customer?: Not only the specific process at the supplier where the forecast is used as input judges the information quality of the forecast, but also the actor operating the process and his/her support. Issues such as user position, knowledge, experience and software support impact the perceived information quality, how well the supplier may utilize the forecast information received from the customer, and consequently also the supply chain performance effects related to forecast information.

- The performance impact: Here, supply chain performance impact was measured as the perceived customer service and the extent of using preventive and corrective actions. The performance impact could be more tightly linked to the supplying company's materials planning or manufacturing process and be measured as the inventory turnover rate, inventory days on hand or the perceived overall performance of manufacturing. Also the user satisfaction among the supplier's planning personnel could be a relevant and interesting measure.

\section{CONCLUSIONS}

The study contains two types of conclusions, those developed from the conceptual discussion in the theoretical framework and those of the empirical study. In the theoretical framework, measurement instruments for FIQ and supply chain performance - the combined effect of corrective actions, preventive actions and customer service performance were developed. FIQ was measured as the four individual variables in time, reliable, accurate and convenient to access, and as an index of the four variables. The measures were tested and used with reliable results in the empirical study. The empirical findings indicated that a large proportion of the suppliers receive customer forecasts, but that the FIQ is lower further upstream in the supply chain. It also showed that the quality variable in time was 
Full reference: Forslund, H. and Jonsson, P. 2007. The impact of forecast information quality on supply chain performance. International Journal of Operations and Production Management, 27(1): 90-107.

considered significantly lower for make-to-order suppliers compared to make-to-stock suppliers, which emphasized the importance of make-to-order companies to receive good forecasts for supply and capacity planning. The only significant difference in supply chain performance found between suppliers with and without access to forecast information was related to the use of safety stock in finished goods inventory. The hypotheses testing did only consider make-to-stock companies, which may explain why the finished good inventory was the most important safety mechanisms against forecast uncertainty.

Research on supply chain information quality is very scarce. Further research is needed to develop the understanding of the performance impact of supply chain information quality, especially FIQ. This study identified several relationships, but it was conducted on a sample with a large spread and in a limited number of companies. Only one of the two hypotheses generated was verified. Therefore, it would be valuable to replicate the study in other empirical settings and for companies with other supply strategies than make-to-stock. Case studies focusing on the actual demand pattern and the processes related to actual forecasting at the customer, transmission of the information from the customer to the supplier, registration of the data at the supplier and the characteristics of the processes and actors using the forecast data could further develop the understanding of the usability of customer forecasts and the perceived performance impact of FIQ.

\section{REFERENCES}

Aviv, Y., 2001. The effect of collaborative forecasting on supply chain performance. Management Science, Vol. 47, No.10, pp. 1326-1343.

Brewer, P.C., Speh, T.W. (2000). Using the balanced scorecard to measure supply chain performance. Journal of Business Logistics, Vol.21, No.1, pp.75-93.

Cachon, G.P., Fisher, M., (2000). Supply chain inventory management and the value of shared information. Management Science, Vol. 46, No. 8, pp. 1032-1048.

Christopher, M., Towill, D. (2000). Supply chain migration from lean and functional to agile and customized. Supply Chain Management: An International Journal, Vol. 5, No. 4, pp. 206-213. Clikeman, P. M. (1999). Improving information quality. The Internal Auditor, Vol. 56, Issue 3, pp. $32-$ 33.

Closs, D. J., Goldsby, T. J., Clinton, S. R. (1997). Information technology influences on world class logistics capability. International Journal of Physical Distribution \& Logistics Management, Vol. 27, No. 1, pp. 4-17.

English, L. P. (1999). Improving data warehouse and business information quality. John Wiley, NY. Ericsson, J. (1997). Störningsanalys av tillverkningssystem - ett viktigt verktyg inom lean production. Doctoral thesis. Department of production and materials engineering, Lund University, Lund.

Fahlén, K. (1997). Störningars konsekvenser för tillverkande företags effektivitet - identifiering, analys och hantering av störningar. Handelshögskolan, Göteborgs universitet (in Swedish).

Forslund (2004), The existence of logistics quality deficiencies and the impact of information quality in the dyadic order fulfillment process, Dissertation No. 62, EKI, Linköping University.

Fliedner, G. (2003), CPFR: an emerging supply chain tool, Industrial Management \& Data Systems, Vol. 103, No. 1, pp. 14-21.

Flynn, B.B., Sakakibara, S., Schroeder, R.G., Bates, K.A., Flynn, E.J. (1990). Empirical research methods in operations management. Journal of Operations Management, vol 9, no 2, pp 250-284. 
Full reference: Forslund, H. and Jonsson, P. 2007. The impact of forecast information quality on supply chain performance. International Journal of Operations and Production Management, 27(1): 90-107.

Frohlich, M.T., Westbrook, R. (2001). Arcs of integration: an international study of supply chain strategies. Journal of Operations Management, Vol. 19, pp.185-200.

Hair, J.F., Anderson, R.E., Tatham, R.L., Black, W.C. (1998). Multivariate Data Analysis, PrenticeHall, Upper Saddle River.

Helms, M., Ettkin, L., Chapman, S. (2000). Supply chain forecasting: Collaborative forecasting supports supply chain management. Business Process Management Journal, Vol. 6, No.5, pp. 392-407. Holmström, J., Främling, K., Kaipia, R., Saranen, J. (2002), Collaborative planning forecasting and replenishment: new solutions needed for mass collaboration. Supply Chain Management: An International Journal, Vol. 7, No. 3, pp. 136-145.

Keebler, J.S., Manrodt, K.B., Durtsche, D. A, Ledyard, D.M. (1999). Keeping score - Measuring the business value of logistics in the supply chain. Prepared for CLM, Oak Brook.

Kelle, P., Akbulut, A. (2005). The role of ERP tools in supply chain information sharing, cooperation and cost optimizing, International Journal of Production Economics, Vol. 93-94, pp. 41-52.

Lee, H., Padmanabhan, V., Whang, S. (1997), Information distortion in a supply chain: the bullwhip effect, Management Science, Vol. 46, No. 4, pp. 546-558.

Lee, Y.W., Strong, D.M., Kahn, B.K., Wang, R.Y. (2002). AIMQ: A methodology for information quality assessment. Information \& Management, Vol. 40, pp. 133-146.

Lindau, R.A. (1995). The impact of high-quality information on performance in manufacturing.

Doctoral thesis, Chalmers University of Technology, Göteborg.

Lindau, R., Lumsden, K., (1993). Disturbance absorption actions used in material flow systems - a

pilot study. Dep. of Transportation and Logistics, Chalmers University of Technology, Göteborg.

Mason-Jones, R, Naylor, B, Towill, D. (2000), Engineering the leagile supply chain, International Journal of Agile Management Systems, Vol. 2/1 pp. 54-61.

Mattsson, S-A. (2002). Logistik i försörjningskedjor. Studentlitteratur, Lund (in Swedish).

McCarthy, T., Golicic, S. (2002). Implementing collaborative forecasting to improve supply chain performance. International Journal of Physical Distribution \& Logistics Management, Vol. 32, No. 6, pp. 431-454.

Mentzer, J.T., Min, S., Zacharia, Z.G. (2000). The nature of interfirm partnering in supply chain management. Journal of Retailing, Vol. 76, No. 24, pp. 549-568.

Moberg, C. R., Cutler, B. D., Gross, A., Speh, T. W. (2002). Identifying antecedents of information exchange within supply chains. International Journal of Physical Distribution \& Logistics Management, Vol. 32, No. 9, pp. 755-770.

Petersen, K. J. (1999). The effect of information quality on supply chain performance: an interorganizational information system perspective. Dissertation, Michigan State University.

Sandberg, E. (2005), Logistics collaboration in supply chains - a survey of Swedish manufacturing companies, Linköping studies in science and technology, Thesis no. 1180, Linköping University, Linköping.

Småros, J. (2003). Collaborative forecasting: a selection of practical approaches. International Journal of Logistics: research and applications, Vol. 6, No.4, pp. 245-259.

Stank, T.P., Emmelhainz, M. A., Daugherty, P.J. (1996). The impact of information on supplier performance. Journal of Marketing theory and practice, Fall, pp. 94-105.

Thonemann, U. (2002), Improving supply-chain performance by sharing advanced demand information, European Journal of Operational Research, Vol. 142, pp. 81-107.

van der Vorst, J., Beulens, A. (2002), Identifying sources of uncertainty to generate supply chain redesign strategies, International Journal of Physical Distribution \& Logistics Management, Vol. 32, No. 6., pp. 409-430. 
Full reference: Forslund, H. and Jonsson, P. 2007. The impact of forecast information quality on supply chain performance. International Journal of Operations and Production Management, 27(1): 90-107.

Vollmann, T., Berry, W., Whybark, C., Jacobs, R. (2005), Manufacturing planning and control for supply chain management, McGraw-Hill, New York.

Wacker, J.G., Lummus, R.R. (2002). Sales forecasting for strategic resource planning. International Journal of Operations \& Production Management, Vol. 22, No. 9, pp. 1014-1031.

Weld, L. (1916), The marketing of farm products, Macmillan, New York.

Whipple, J.M., Frankel, R., Daugherty, P.J. (2002). Information support for alliances: performance implications. Journal of Business Logistics, Vol. 23, No. 2, pp. 67-82.

Zhao, Y. (2002), The value of information sharing in a two-stage supply chain with production capacity constraints: The infinite horizon case. Manufacturing \& Service Operations Management, Vol. 4, No. 1, pp. 21-24. 
Full reference: Forslund, H. and Jonsson, P. 2007. The impact of forecast information quality on supply chain performance. International Journal of Operations and Production Management, 27(1): 90-107.

\section{Autobiographical note}

Helena Forslund PhD

Department of Logistics \& Supply Chain Management

School of Management and Economics

Växjö University

SE-351 95 Växjö, Sweden

+46 470708784 (phone)

+4647083092 (fax)

+4670577 7822 (mobile)

helena.forslund@lnu.se

Patrik Jonsson PhD

Division of Logistics and Transportation

Chalmers University of Technology

SE-412 96 Göteborg, Sweden

+46 317721336 (phone)

+4631 (fax)

+4673034 6393 (mobile)

patrik.jonsson@chalmers.se 